Wires, L. R. 2015. Migratory bird protection, a crack in the armor: the case of the Double-crested Cormorant. Avian Conservation and Ecology $\mathbf{1 0}$ (1): 8. http://dx.doi.org/10.5751/ACE-00761-100108

Copyright (C) 2015 by the author(s). Published here under license by the Resilience Alliance.

\title{
Migratory bird protection, a crack in the armor: the case of the Double- crested Cormorant
}

Linda R. Wires ${ }^{1}$

${ }^{1}$ Department of Fisheries, Wildlife and Conservation Biology, University of Minnesota

\section{Protection des oiseaux migrateurs, une fissure dans l'armure : le cas du Cormoran à aigrettes}

Key Words: cormorants; management; Migratory Bird Treaty Act; persecution; protection

\section{INTRODUCTION}

The year 2016 marks the centennial of the convention between the United States and Great Britain (for Canada) for the Protection of Migratory Birds. Signed on 16 August 1916, this historic convention originated out of the need to protect birds from a long tradition of overuse and destruction. In Canada the Migratory Birds Convention Act, 1994 (MBCA) was passed in 1917, while in the United States the Migratory Bird Treaty Act (MBTA) was passed in 1918. These acts resulted in the implementation of the convention in each country and provided protection under the law to migratory birds, their nests, and eggs. This protection represents a milestone in bird conservation efforts. To celebrate the centennial, increase awareness of migratory birds, and prepare for the next century of migratory bird conservation, the U.S. Fish and Wildlife Service (USFWS) is planning multiple activities that will occur throughout 2015-2016 (http://www.fws. gov/birds/MBTreaty100/). Environment Canada has not yet announced plans for centennial celebrations, but presumably will also undertake activities to celebrate this event.

While this centennial is being celebrated, another 100th anniversary with great resonance for migratory birds was also recently commemorated: in 2014, we marked the centennial of the Passenger Pigeon's (Ectopistes migratorius) demise. For this species, we know the exact day the world's last known individual departed, 1 September 1914. Once the most abundant bird in North America, the Passenger Pigeon's dramatic decline began about the mid-19th century and was a direct result of human activity, exploitation, and persecution. By the turn of the century, the species was gone from the wild and the only birds that remained were in captivity. The last of these was Martha, an individual who spent her twilight years alone at the Cincinnati Zoo and received much notice as the sole representative of her kind. With Martha's passing, the Passenger Pigeon slipped permanently into oblivion. This sad occurrence was commemorated in 2014 by numerous events held around the continent to reflect on the loss and to highlight current conservation challenges. Quite possibly the world's most abundant bird ever, the potential for the Passenger Pigeon's extinction was inconceivable to most. However, it was annihilated in just decades. As such, the Passenger Pigeon has become one of the great icons of extinction, and its tragic history is a powerful reminder for why we need conservation science. Martha will no doubt remain in sharp focus as centennial celebrations for migratory bird protection get underway.

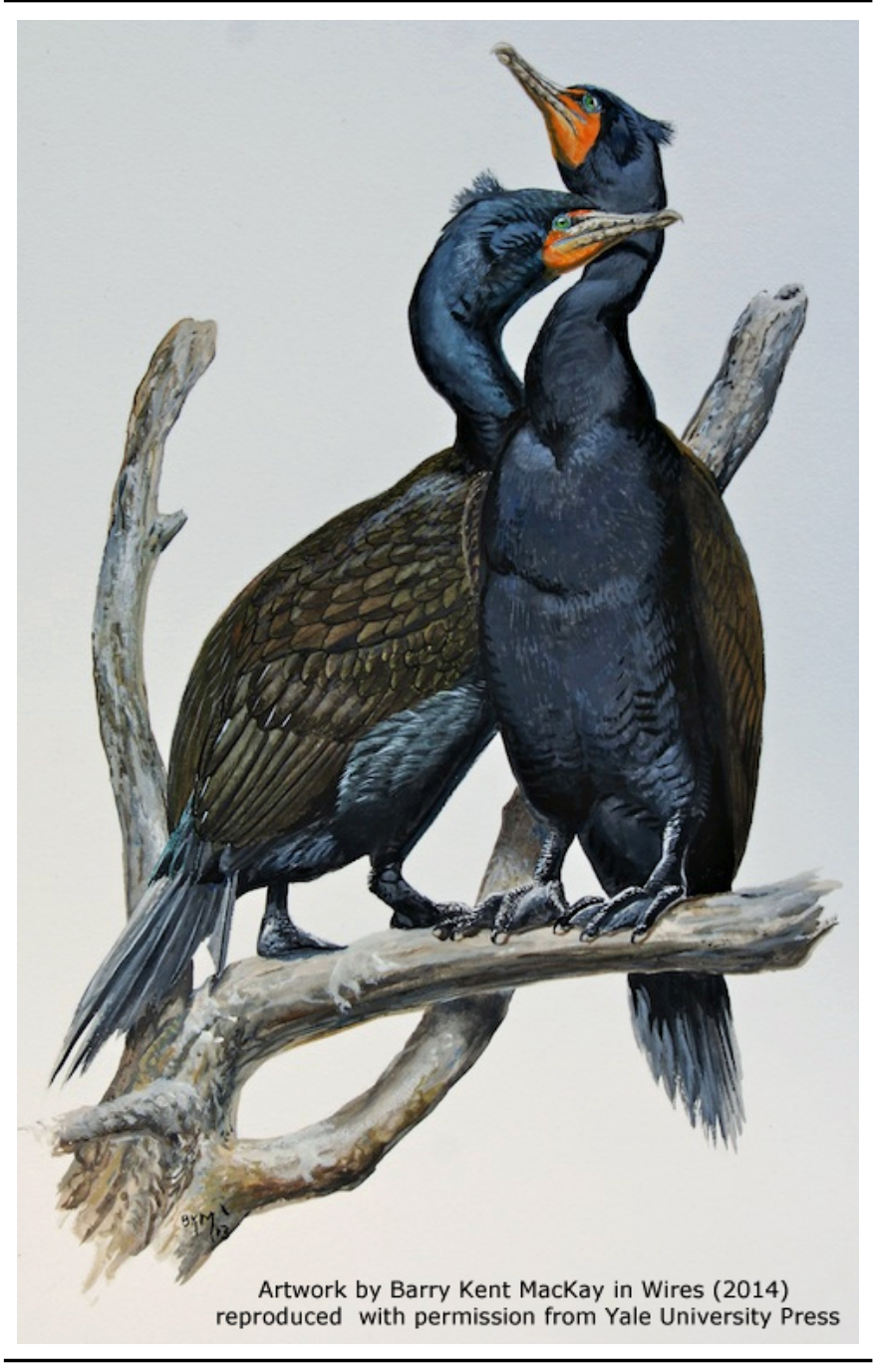


How ironic then, that as these sobering lessons of history are commemorated, and we celebrate the critical institutions established to protect birds, another iconic species has recently become the recipient of what can best be described as institutionalized persecution. The Double-crested Cormorant (Phalacrocorax auritus, herein cormorant), long hated for its fishing prowess, is no stranger to human efforts to diminish its numbers or eradicate its presence. Indeed, the persecution of this species has been ongoing for centuries, with origins dating back to the arrival of European settlers to North America. What is relatively new, however, is that in the U.S., the irrational attitudes that have driven this treatment have now found legitimacy in federal regulations established by the agency officially tasked with protecting migratory birds in America. Between 1998 and 2003, the USFWS established two depredation orders for cormorant management in the eastern U.S. (USFWS 2003). In little more than a decade, their use by state, tribal, and federal agencies, as well as private citizens, resulted in the destruction of roughly half a million cormorants and hundreds of thousands of their nests (USFWS 2014a, Wires 2014), despite little biological evidence justifying this as a rational course of action. In Canada, no federal regulations for cormorants have developed, and management by provincial agencies has been comparatively minimal. Nevertheless, during the same time period (late 1990s-2012), a handful of provincial programs destroyed at least 30,000 birds and oiled possibly hundreds of thousands of eggs; in addition, a well-established tradition of destruction by commercial fishermen continued to target thousands of cormorants on Lake Winnipegosis, Manitoba (Wires 2014). These events led me to chronicle the evolving history of cormorant persecution in Wires 2014. In the short time since the book's publication, additional management indicates that the destructive approach to cormorants is expanding in the U.S., and irrational attitudes toward cormorants have continued to gain ground as they are sanctioned by government management policy. Therefore, in the midst of events to celebrate migratory bird protection and remind us of why it is necessary, reflecting upon the cormorant's present day treatment is timely.

\section{CORMORANT PROTECTION AND MANAGEMENT IN CANADA}

Cormorant management in Canada through 2012 is summarized in Wires 2014, and abbreviated here. In Canada, cormorants are not federally protected under the MBCA. Instead, these birds are protected by acts of the provincial legislatures, which also have responsibility for managing the species. Among provinces, management practices vary, and since the late 1990s, significant cormorant management by agencies, i.e., targeting destruction of several hundreds or thousands of birds or nests, has occurred only in Alberta, Ontario, and Quebec. Management to benefit fisheries interests, e.g., to recover historical fish communities and/or increase allocations of fisheries to humans, has occurred only in Alberta and Quebec, which have undertaken shooting and eggoiling programs at colonies in just two areas for this purpose, Lac La Biche region, Alberta and Lac St. Pierre, Quebec. In Ontario, provincial agencies have managed cormorants because of concerns about negative ecological impacts to specific habitats or other species. To address these concerns, agencies have taken different approaches. Large-scale shooting and egg-oiling programs were pursued at two locations, Presqu'ile Provincial Park, and Middle Island, Point Pelee National Park. Conversely, at Tommy Thompson Park, home of the largest colony of Doublecrested Cormorants in eastern North America, only nonlethal efforts have been employed. In addition, management at Presqu'ile Provincial Park shifted to nonlethal and deterrent techniques in 2007. Under Ontario's cormorant management policy, management to benefit fisheries is not undertaken; however, the Ontario Ministry of Natural Resources conducted an experimental egg-oiling program for several years in Lake Huron to determine if cormorants affected coastal fish abundance.

Justification for the recent management that has occurred has been questioned and challenged, and significant concerns that much of this management is unwarranted and persecutes cormorants have been raised (Wires 2014). In addition, cormorants have endured a long history of illegal persecution in some areas of Canada, and can be legally killed in some provinces by landowners on private lands. However, as a whole, recent government-sanctioned management in Canada has been much more infrequent than that in the U.S., despite Canada supporting proportionally larger numbers of breeding cormorants. In addition, although numbers killed legally on private lands are not known, they are not believed to be comparable to those destroyed under legal means in the U.S. Moreover, through the significant nonlethal efforts undertaken at Tommy Thompson Park, Canada provides at least one unique model in which diverse stakeholder views and values are incorporated, and some of the techniques practiced here have replaced destructive efforts at Presqu'ile Provincial Park. Finally, since the summary provided through 2012 (Wires 2014), there has been no expansion of significant lethal management by provincial agencies in Ontario or Quebec. For Alberta, however, current status of management efforts could not be confirmed. Because developments in cormorant management have been much more extreme in the U.S., the rest of this reflection will concentrate on management in that country.

\section{CORMORANT PROTECTION AND MANAGEMENT IN THE U.S.}

In the U.S. cormorants gained federal protection under the MBTA in 1972. To manage migratory birds protected under the MBTA, the USFWS issues depredation permits, and, for a limited number of species, also allows take, i.e., kill, under depredation orders. The first depredation order for cormorants, the Aquaculture Depredation Order (AQDO), was established in 1998 and is in effect in 13 states, 12 in the southeast and in Minnesota. The AQDO authorizes fish producers, their employees, or designated agents at commercial aquaculture facilities, mainly catfish farms, and at federal- and state-owned fish hatcheries to shoot unlimited numbers of cormorants without a permit during daylight hours when they are found committing or about to commit depredations to aquaculture stocks. In addition, it authorizes employees of the Wildlife Services program of the U.S. Department of Agriculture (USDA) and their designated agents to kill cormorants, with appropriate landowner permission, at roost sites in the vicinity of aquaculture facilities, at any time, day or night, from October through April (USFWS 2003). Between 1998 and 2012, approximately 300,000 
cormorants were killed under this order (Wires 2014, USFWS 2014a). In 2003, the Public Resource Depredation Order (PRDO) followed, and is in effect in 24 states east of the continental divide. The PRDO "authorizes State fish and wildlife agencies, Federally recognized Tribes, Wildlife Services [and designated agents of these agencies and tribes] to prevent depredations on the public resources of fish, wildlife, plants, and their habitats by taking without a permit cormorants found committing or about to commit, such depredations" (USFWS 2003:58035). Take began under this order in 2004, and by the end of 2012, 173,070 cormorants were killed (USFWS 2014a). Common to both orders is a lack of standards for science-based decision making and any requirement for science-based evidence that should inform the management of wildlife populations. In Wires 2014, I provide numerous examples of how this oversight has resulted in liberal applications and interpretations of the orders. In addition, I identify an important lack of federal oversight in their use, and an apparent disregard for best ecological practices in their establishment. Here, I focus on how these shortcomings have been particularly significant in the application of the PRDO, because it is this order that most undermines protection associated with the MBTA.

\section{The Public Resource Depredation Order}

Although more birds have been killed under the AQDO, this order has been in effect for seven years longer than the PRDO. As of 2007, annual averages of birds killed under the PRDO have been about 33\% higher than those under the AQDO (USFWS 2014a). The PRDO has a much broader geographic range, addresses a wider variety of conflicts, and targets birds on both the breeding and wintering grounds, thus giving it a much greater reach than the AQDO. In addition, two other features of the PRDO facilitate a much wider application of this order. First, the PRDO's identification of fish, wildlife, plants, and habitats as "public resources" essentially puts all of the elements cormorants need to interact with in their daily existence off limits to them. Second, the USFWS specifically avoided providing any guidelines as to what actually constitutes a "public resource depredation." This omission is significant because the acts of eating, nesting, roosting, defecating, and many other natural behaviors do affect resources in some way; without guidelines, the behaviors themselves can be considered "depredations" in almost any given situation. This has resulted in great latitude in how take under this order occurs. In Wires 2014, I presented many examples of cormorant control initiated under the PRDO that were based simply on descriptions of concern, suspicion of impacts, or belief that cormorants will affect resources in a negative way simply by interacting with them. Here, I review examples documented in Wires 2014, and identify new developments that reveal how take under the PRDO has now established a pattern of destruction as the general approach to managing cormorants.

\section{The Great Lakes Region}

Between 2004 and 2012, 126,027 cormorants were killed in five Great Lakes states (MI, MN, NY, OH and WI; USFWS 2014a). With the exception of birds shot in Ohio, most of these birds were killed because of concerns about fisheries and destroyed with what agencies identified as an adaptive management approach. This approach is applied in situations where there is limited understanding of resource systems and uncertainty about potential responses to management actions, and provides for simultaneously managing and learning about natural resources in an experimental context. However, there is considerable ambiguity about what adaptive management actually is, and how it is to be implemented. In practice, the term has been inappropriately applied so frequently that several recent publications define criteria for implementing adaptive management more specifically (Williams et al. 2009, Doremus et al. 2011, Williams 2011). Essential criteria include the following: the existence of information gaps where learning would help achieve management goals; good prospects for learning with the ability to narrow information gaps over a management-relevant time scale; opportunities to adjust and change management direction in response to learning; and the ability to develop an effective monitoring program to evaluate resource response to management action. To determine if these criteria were being met, I reviewed cormorant management practices in the U.S. Great Lakes that agencies identified as adaptive management projects (Wires 2014). This review indicated that although there were often information gaps for which learning could help achieve management goals, in general the science used to address these gaps was insufficient; prospects for learning over a managementrelevant time scale were limited because of rapidly evolving environmental conditions and ecological processes, as well as only partial controllability of factors affecting resources; all programs were limited in their ability to develop effective monitoring programs; and all programs were limited in their ability to change management direction in response to learning. Overall, management efforts did not meet basic criteria to qualify as truly adaptive programs that led to knowledge-based solutions. For most programs, the lack of investment in good science offered no way to discern that cormorants were not "killed wantonly," and thus management efforts in the Great Lakes could not be distinguished from programs of "just killing nuisance wildlife," a pitfall of many wildlife culling programs (Warburton and Norton 2009).

\section{Texas}

In Texas, there has been no pretense of experiment or adaptive management. Instead, under authority granted by the PRDO, Texas Parks and Wildlife Department (TPWD) simply established a "Nuisance Double-crested Cormorant Control Permit" (http:// tpwd.texas.gov/business/permits/land/wildlife/cormorant/), to provide "depredation relief" to "local areas in Texas besieged by the double-crested cormorant" (TPWD 2004). This permit is available to any landowner who possesses a valid Texas hunting license and pays a fee of $\$ 13$. Those issued permits are designated as agents of Texas Parks and Wildlife, and can kill unlimited numbers of cormorants on private lands for which their permit is issued. Despite the fact that the PRDO was established to protect public resources, a liberal interpretation by the USFWS deemed the Texas permit as a plausible use of the PRDO. The USFWS noted that cormorants,

undoubtedly depredate without bias on both private and public resources on both private and public ownerships. Accordingly, it may be presumed that control efforts to alleviate depredation impacts to one ownership category benefit the other... Therefore, if TPWD determines that public resource interests will be served by controlling double-crested cormorants on private lands/waters, they 
or their agents may implement control activities as long as landowner permission is received (USFWS letter authorizing this use of PRDO, as cited in Wires 2014).

Take in this way began in 2005, and as of 2012, 29,741 cormorants had been reported killed in Texas under this permit (USFWS 2014a).

In 2014, the USFWS developed a draft environmental assessment for extending the depredation orders, which were set to expire in June of 2014. During this process the USFWS received multiple comments pointing out that the Texas Nuisance Permit does not comply with the terms of the PRDO. This observation was also detailed in Wires 2014. In response to the comments, the USFWS acknowledged that,

Texas Administrative Code Rule $\$ 65.901$ appears not to comply with 50 CFR 21.48 because it allows take of [cormorants] on private land even though the [cormorants] are not necessarily linked to any adverse effect on public resources. We will work with the State of Texas on this issue, and if the State does not revise its code to match the provisions of 50 CFR 21.48, we will remove Texas from the list of States that are authorized to implement the Public Resource Depredation Order.

This comment was published by the USFWS on 28 May 2014 (USFWS 2014b:30479) but as of June 2015, the Nuisance Permit application was still available on the TPWD web site. To date, the agency has not revised the terms for take and is still issuing the permit under the PRDO.

\section{South Carolina}

Recently, the state of South Carolina also developed a permitting system under the PRDO, called the "Santee Cooper Cormorant Removal Program" (SC DNR 2013). In 2014, nearly 1100 citizens were designated as agents of the South Carolina Department of Natural Resources (SC DNR) and authorized under the PRDO to shoot unlimited numbers of cormorants on the Santee Cooper Lakes during the month of February from sunrise to sunset (SC DNR 2013, Peterson 2015). The reasons stated for this "removal program" included cormorant competition with the resident fish population for forage fish, cormorant predation on various fish species valued by humans, cormorants harassing adult redear sunfish (Lepomis microlophus), and permanent damage to trees used for roosting (SC DNR 2013). However, no information was provided on the SC DNR web site that actually documents these allegations or indicates how they are biologically meaningful. Nevertheless, during the first year of this permitting system 11,653 cormorants were reported to be killed (Holleman 2014); in reality, the number may have been higher because only $520(\sim 50 \%)$ individuals that were issued permits actually returned the required reports about the number of birds they killed. The permit was available again in 2015, but at the time of this writing, no information was available about the number of birds killed with the 2015 permits.

\section{Columbia River Estuary, Oregon}

Although the PRDO does not authorize cormorant control west of the continental divide, the model of cormorant destruction that has emerged in the eastern U.S. under this order is now being exported to the west. At the mouth of the Columbia River, the largest colony of Double-crested Cormorants in the world nests on East Sand Island, a 24 ha island owned by the U.S. Army Corps of Engineers (USACE). In 2013, this colony comprised about 15,000 pairs of Double-crested Cormorants, and accounted for approximately $40 \%$ of the western population of this species. In 2015, USACE finalized an Environmental Impact Statement for cormorant management in the Estuary, in the hopes of improving survival of juvenile salmonids, several species of which are threatened or endangered. To this end, USACE is targeting a colony size of 5600 pairs on the island and plans to destroy 11,000 birds and oil eggs over a four year period (USACE 2015). The USACE received over 152,000 comments on the Draft Environmental Impact Statement, the vast majority criticizing its plans for cormorant control. Most of these were obtained through two online petitions (CARE2 and National Audubon Society). Many comments suggested that the USACE should consider other methods to manage the problem, such as altering flow management, removal of dams, habitat restoration, etc., rather than managing native wildlife to improve salmonid populations. Substantive comments were also submitted by scientists, conservation biologists, and waterbird experts who challenged the methodologies, alternatives, and assumptions of effects (USACE 2015). Despite these comments, the USFWS issued a depredation permit authorizing this management. In response, a lawsuit was filed against the USACE, USFWS, and USDA-Wildlife Services by Audubon Society of Portland, Center for Biological Diversity, Wildlife Center of the North Coast, Animal Legal Defense Fund, and Friends of Animals. Nevertheless, shooting and egg oiling began on the island in May 2015 (http://audubonportland.org/ issues/habitat/sand-island).

\section{CONCLUSIONS}

All combined, these examples indicate that although cormorants have been protected on paper by the MBTA since 1972 in the U. S., the PRDO has essentially rendered this protection meaningless. With the PRDO, we have a policy that does not promote knowledge-based solutions; instead, it provides a mechanism by which tens of thousands of birds can be killed for engaging in natural behaviors and fulfilling their role as piscivores in natural environments. Cormorants are now safe nowhere. The PRDO has enabled cormorant control to occur on National Wildlife Refuges that were established for the protection of native birds, and on federal wilderness areas that were set aside to preserve wilderness-pristine places affected by the forces of nature rather than by human interests. Even on private lands purchased by NGOs to protect birds and wildlife, cormorants are not safe. For example, in Michigan, birds nesting on islands purchased by the Michigan Nature Association are targeted and shot when they fly 500 meters from the island's shore, because the waters surrounding these islands are in public ownership (Wires 2014). In addition, the opinions of NGOs that specialize in bird conservation and preservation appear to hold no sway, nor do the opinions of hundreds of thousands of their members.

Thus far, the legal system, too, has been unable to bring protection to cormorants in the U.S. As the destructive approach to cormorants began developing, the USFWS was sued in 1999 for issuing depredation permits and again in 2003 for establishing the depredation orders. In both of these cases, plaintiffs charged that cormorant management authorized by USFWS permits and 
regulations violated both the MBTA and the National Environmental Policy Act (NEPA; Wires 2014). However, each time the court found in favor of the USFWS. Presently, the courts have yet another opportunity to weigh in on cormorant management, for in addition to the lawsuit over the Columbia River situation, the USFWS is also facing a legal challenge regarding its decision to renew the depredation orders. Prior to this decision, the agency was required to conduct a thorough review of impacts under the orders and consider potential revisions to regulations for cormorant management. But it failed to do so; instead it simply noted that "resource limitations preclude completion of a thorough review of potential revisions to the regulations prior to the 30 June 2014 expiration dates" and extended the orders for another five years (USFWS 2014a:2). This was the second such extension of these orders; the first occurred in 2009. The legal challenge to this action was filed in 2015 by Public Employees for Environmental Responsibility, along with private citizens, several of whom are wildlife scientists, including one recently retired from the USFWS. They claim that the USFWS is in violation of NEPA for not conducting the full review before renewing the orders (PEER 2014).

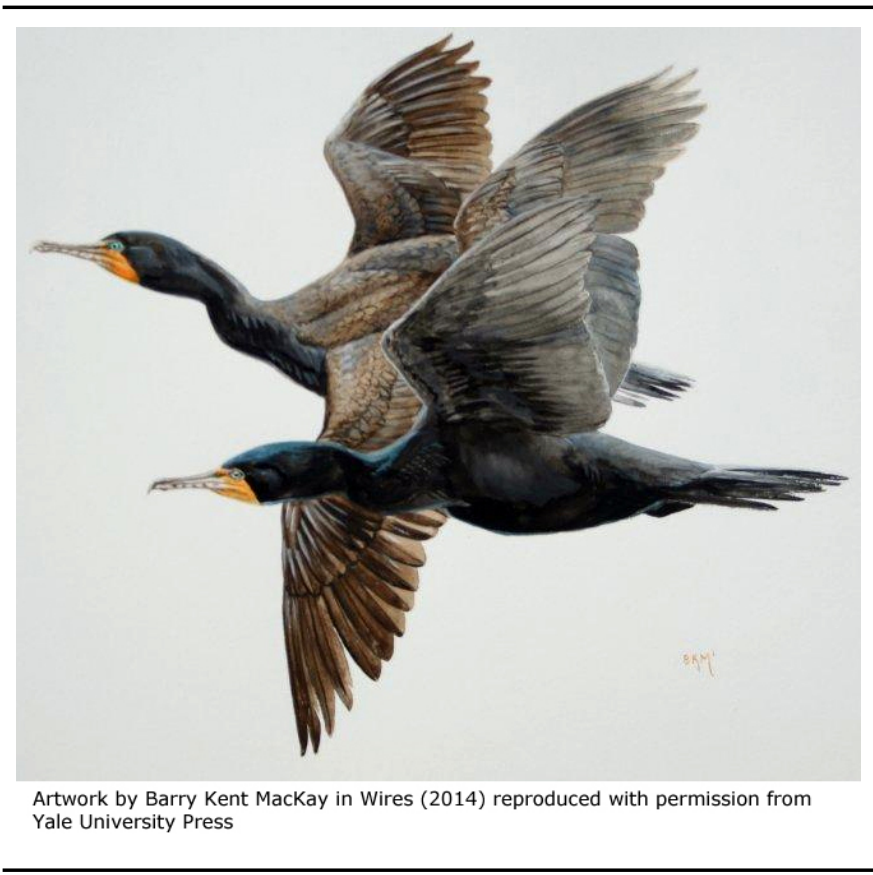

Double-crested Cormorants occur only in North America, with most of their breeding population centered in the U.S. and Canada. As such, the populations in these countries are globally significant. Therefore, the U.S. and Canada have an even greater obligation to manage these birds responsibly and find solutions that do not simply perpetuate a long tradition of destruction. Going forward into the next century of bird conservation, it is fundamental to recognize that the PRDO signals a major crack in the armor of bird protection provided by the MBTA. Although many different factors have influenced cormorant management in the U.S. and Canada (Wires 2014), both countries have segments of the public that demand cormorant control. In this context, it is remarkable that even while cormorants have not been federally protected in Canada, far fewer have been killed on Canadian soil under government sanctioned programs than in the U.S. This observation makes the pattern that has emerged in the U.S. even more troublesome, because the level of destruction that has occurred in this county is not only so much greater, but has occurred while the birds were federally protected. For the MBTA to remain resilient and actually protect cormorants on $U$. S. soil, the agency responsible for migratory bird protection must acknowledge that the PRDO is not only heavily flawed, but moreover has become the cornerstone by which modern-day persecution of a federally protected bird now thrives. If the annual destruction of tens of thousands of cormorants based on suspicion, dislike, and mismanagement of resources does not constitute a violation of the MBTA, then conservation scientists and those committed to bird protection must go back to the drawing board to establish effective wildlife conservation policy.

Responses to this article can be read online at: http://www.ace-eco.org/issues/responses.php/761

\section{LITERATURE CITED}

Doremus, H., W. L. Andreen, A. Camacho, D. A. Farber, R. L. Glicksman, D. Goble, B. C. Karkkainen, D. Rohlf, A. D. Tarlock, S. B. Zellmer, S. Jones, and Y. Huang. 2011. Making good use of adaptive management. White Paper 1104. Center for Progressive Reform, Washington, D.C., USA. [online] URL: http://www. progressivereform.org/CPRBlog.cfm?idBlog=4A76EB07-B349-6A27FDD3A365964804C6

Holleman, J. 2014. Exclusive: SC hunters kill more than 11,000 cormorants. The State, 4 Apr. [online] URL: http://www.thestate. com/news/local/article13846073.html

Peterson, B. 2015. Lawsuit challenges special-permit cormorant hunt on Moultrie, Marion lakes. The Post and Courier, 8 February. [online] URL: http://www.postandcourier.com/article/20150208/ PC16/150209540

Public Employees for Environmental Responsibility (PEER). 2014. Suit to nix Double-crested Cormorant shoot-on-sight orders. PEER, Washington, D.C., USA. [online] URL: http://www.peer. org/news/news-releases/2014/10/29/suit-to-nix-double-crested-cormorantshoot-on-sight-orders/

South Carolina Department of Natural Resources (SC DNR). 2013. DNR begins program for removal of Double-crested Cormorants from Santee Cooper lakes. DNR News, 20 November. [online] URL: http://www.dnr.sc.gov/news/yr2013/nov21/ nov21_cormorant.html

Texas Parks \& Wildlife Department (TPWD). 2004. New Release. Texas finalizes cormorant control permit. TPWD, Austin, Texas, USA. [online] URL: https://tpwd.texas.gov/newsmedia/releases/? req=20040830b Accessed June 8, 2015.

U.S. Army Corps of Engineers (USACE). 2015. Double-crested Cormorant management plan to reduce predation of juvenile salmonids in the Columbia River Estuary. Final Environmental Impact Statement. USACE, Portland, Oregon, USA. 
U.S. Fish and Wildlife Service (USFWS). 2003. Migratory bird permits: regulations for Double-crested Cormorant management. Final Rule. Federal Register 68(195):58022-58037. USFWS, Arlington, Virginia, USA.

U.S. Fish and Wildlife Service (USFWS). 2014a. Final environmental assessment: management of Double-crested Cormorants under 50 CFR 21.47 and 21.48. USFWS Division of Migratory Bird Management, Arlington, Virginia, USA, in cooperation with U.S. Department of Agriculture, Animal and Plant Health Inspection Service, Wildlife Services, Washington, D.C., USA.

U.S. Fish and Wildlife Service (USFWS). 2014b. Migratory bird permits; extension of expiration dates for Double-crested Cormorant depredation orders. Federal Register 79(102):30474-30483. USFWS, Arlington, Virginia, USA.

Warburton, B., and B. G. Norton. 2009. Towards a knowledgebased ethic for lethal control of nuisance wildlife. Journal of Wildlife Management 73:158-164. http://dx.doi.org/10.2193/2007-313

Williams, B. K. 2011. Adaptive management of natural resources: framework and issues. Journal of Environmental Management 92:1346-1353. http://dx.doi.org/10.1016/j.jenvman.2010.10.041

Williams, B. K., R. C. Szaro, and C. D. Shapiro. 2009. Adaptive management: the U.S. Department of the Interior technical guide. U.S. Department of the Interior, Adaptive Management Working Group, Washington, D.C., USA.

Wires, L. R. 2014. The Double-crested Cormorant: plight of a feathered pariah. Yale University Press, New Haven, Connecticut, USA. 